\title{
Innovation in construction materials engineering versus sustainable development
}

\author{
L. CZARNECKI ${ }^{1 *}$ and D. VAN GEMERT ${ }^{2}$ \\ ${ }^{1}$ Building Research Institute, ITB, Warsaw \\ ${ }^{2}$ KU Leuven \& Triconsult N.V.
}

\begin{abstract}
Innovation in construction is presented as a necessary aspect in the answer that the construction industry must provide to solve its negative impact on the environment. Original and innovative research is only part of the work to be accomplished. More important is the implementation of innovation in practice, where traditions are strongly rooted in society, and safety and long term reliability are required. Lessons from nature and study of durable examples handed down from the pasts serve as guidelines to innovative approaches that contribute to sustainability.
\end{abstract}

Key words: sustainability, construction, innovation, waste prevention, building technology evolution.

\section{Introduction}

Nowadays, "innovation" becomes a key word of modern economy but it seems to be the new global obsession also in engineering.

Contemporarily as well as in the past construction innovations are hot spots in engineering science. Only this year the Construction Industry Council in Hong Kong launched the "Innovation Construction Award" oriented particularly towards sustainable development [1]. Ten years ago the Chartered Institute of Building (CIOB). i.e. the world's greatest organization in the field of construction management, published a report [2] under the significant title of "Innovation in construction: ideas are currency of the future". Those examples, distant in time (10 years) and in space (British Isles and Hong Kong), document longevity of the problem. Just recently (October 2017), the $63^{\text {rd }}$ Scientific Conference of Civil Engineering of the Polish Academy of Sciences and the Science Committee of the Polish Association of Construction Engineers and Technicians has formulated the Innovative Challenges of Building Technologies. The subject matter does not lose its validity but even brings about some new problems due to several reasons. An attempt has been made to define the paradigm of civil engineering development and to depict a wider view of knowledge-based construction engineering [3].

Innovation means the successful exploitation of new ideas. More precisely, innovation will be defined as the successful introduction of new technologies or procedures into industry. In such cases, Research and Development (R\&D) will be understood as the process that is undertaken to introduce innovation into industry. Continuous innovation is vital for sustainable development of the construction industry. Creative ideas and

*e-mail: 1.czarnecki@itb.pl

Manuscript submitted 2017-11-23, initially accepted for publication 2017-11-24, published in December 2017. innovative solutions are recognized as important levers to effect growth and efficiency, especially in today's dynamic world. The conviction that ideas should and did outrun innovation has been demonstrated in publication [4]. The aim of this study is to underline the scientific background of construction innovation. Construction innovation occupies a special position amongst engineering innovation due to the scope of its impact, and responsibility related to construction and use of building structures. For this purpose, the definition of construction innovation needs to be formulated together with its specific challenges, limitations and possibilities.

\section{Conditioning of construction innovation}

2.1. Construction innovation versus fundamental requirements (CPR-EU 305/2011). Innovation means each change. There exist product, process, organization and marketing innovations. Just "doing something" but only something related to construction could be extremely bad to the construction itself and even for its surroundings.

Innovations are endless on the side of positive results, but on the negative side a catastrophe, understood as the fall of the continuum, is the obvious barrier in the material and conceptual senses [5]. A building breakdown or even collapse could also be the source of innovative solutions [6]. It is an example of a smart use of unfortunate or even catastrophic events as a lesson to learn for the future. It is most painful and costly but generally a very effective source of innovation.

Due to the safety and responsibility aspects, building construction activity has always come under so-called fundamental requirements, ever since the times of the Hammurabi Code (1750 BC) and later of Marcus Vitruvius, author of De architectura $(50 \mathrm{BC})$. Presently, construction fundamental requirements are described in the European Basic Requirements for Construction Works, CPR-EU 305/2011. 
The construction industry uses $42 \%$ of all generated power and emits $35 \%$ of all greenhouse gases. The branch of the world concrete industry alone uses 20 billion tons of aggregates, 4 billion tons of cement and 800 million tons of water per year.

These huge amounts of material consumption necessitate the implementation of the principles of sustainable development in construction, which has found its official acknowledgment in an initiative of the European Commission. It took a quarter of a century since Brundtland's concept until an adequate Regulation has been implemented (Table 1). In March 2011 the new version [7] of Basic Requirements for Construction Works, CPR-EU 305/2011, was announced. These are:

1. Mechanical resistance and stability;

2. Safety in case of fire;

3. Hygiene, health and the environment;

4. Safety and accessibility in use;

5. Protection against noise;

6. Energy economy and heat retention;

7. Sustainable use of natural sources (new requirement, 2011).

Table 1

Sustainable construction: from concept to European Construction Product Regulation, CPR [8]

Concept: G.H. Brundtland, UN, 1997. "Development that by satisfying the current needs would not limit the ability of satisfying needs of next generations"

\begin{tabular}{|l|l|l|}
\hline \multicolumn{3}{|l|}{ Principle: H. Daly, 1996 [9] } \\
\hline $\begin{array}{l}\text { Consumption of sources/wastes } \\
\text { and by-products production }\end{array}$ & $\begin{array}{l}\text { Environmental } \\
\text { Impact }\end{array}$ & Sustainability \\
\hline Faster than natural regeneration & Degradation & None \\
\hline Equal to regenerative potential & Balance & Steady state \\
\hline $\begin{array}{l}\text { Slower than regenerative } \\
\text { potential }\end{array}$ & Regeneration & Development \\
\hline
\end{tabular}

\section{CEN TC350 European Committee for Standardization:} Sustainability of Construction Works, 2005

Construction Product Regulation CPR-EU 305/2011:

The construction works must be designed, built and demolished

in such way that the use of natural sources is sustainable and,

in particular, ensures the following:

a) reuse or recyclability of the construction works, their materials and parts after demolition;

b) durability of the construction works;

c) use of environmentally compatible raw and secondary materials in the construction works.

Additionally, due to the $7^{\text {th }}$ requirement, it should be stressed that the required durability of the construction works is 50 years + , which has no competitors among engineering products whatsoever.

The users should have certitude that the built works in which they are located, set to give them security and comfort of use, are based on scientific research [10]. Those are the ethical warrants rooted deeply into the heart of man and in the adequate codes which define what it means to be professional.
Beside all those formal and substantive restrictions relevant to building innovation, some optimistic advantage should be underlined. The building industry is the domain which since ever has kept up with the constant growth in the quantity and quality of human needs (shelter, transport, storage, but also cultural objects and civilization monuments). Thus internal development has been conditioned by outer constraints.

\subsection{Construction innovation versus traditional building con-} servatism. There is no other discipline in which final products have their lifetime longer than the designer's life expectancy. In such case durability and reliability are very peculiar attributes of the civil engineering discipline as an applied science. Consequently, existing constructions exploited under rather complicated conditions need diagnosis of their current technical status. A newly erected structure should be preceded by risk analysis and evaluation. Those are the reasons of some conservatism, or rather circumspection, so symptomatic for implementation of building innovation in practice. Building innovation by its very nature should not be "firework". In construction, "new" does not necessary mean "better". This means that it is not enough for a building to meet the requirements at the time of testing. We need to ensure that it will also meet those requirements in in the future: for how long are the performances assured? The building service life must be predicted and a prognosis of service life is needed [11]. This is an extremely complicated issue. At the engineering level, for instance, more than 30 factors can be mentioned which affect the durability of concrete structures [10].

It is of significance that for several years now there has been a lack of civil engineering topics on the Research Front Maps [4], even though they are being updated every two months. Also, it is difficult to find an organization involved particularly with building technology among the 200 top institutions influencing inventions $[12,13]$.

At the same time, the building industry is kept under continuous pressure of demography needs. Progress in building technology means building up a balance between the growth fetish (quantity) and development fetish (comfort of using). There are also natural barriers. The tremendous amount of material mass consumed annually by the building industry is in conflict with the available raw materials in the upper layer of the geosphere and with existing aggregated deposits. That is the reason why a competitor for Portland cement has not been found. Consequently, the same applies to concrete, too. The progress of fundamental construction materials has taken place by modification but not by the substitution.

In general, progress in civil engineering is done by evolution and not by revolution. That is a result of better understanding of composite materials' nature, gathering building experience and cultivate designing methods. Innovation could be a result of research but could also be a technical novelty not involved with research programs. However, it is necessary for building innovation coming from sources other than scientific research to be carefully verified and validated [10] by knowledge-based test programs. We should not only be focused on the given "innovative element" but look at the building 
as a whole. Certainly innovations call to go beyond what is currently possible, and this call captures the public imagination. However, in civil engineering we should play it safe accordingly to the basic requirement for construction works (see chapter 2.1). This does not stop the building innovation but it makes it more sophisticated.

2.3. Learning from nature. Man's basic need, besides food and clothing, has always been protection from the elements: heat of the sun, torrential rain and cold. The very first time man realized the concept of building might have been the times when they gathered around a fire and hid themselves between rocks, sheltered against cold [14]. This has awakened the idea of using stones as protection from the weather. However, observation and experience of natural phenomena as well as observation of fauna and flora in nature have always been a driving force for innovation in construction and building materials, leading from originally simple use of available materials to eventually real engineering and production of building materials for specific goals and use.

A deeper study of animal building behaviour reveals astonishingly refined structures and complex "architectural" principles. In terms of precision, animal constructions often surpass human skills of construction. It is evident that the structures animals build for themselves and their offspring are just as essential for their existence as architecture is for us. Animal constructions serve the same fundamental purpose as human constructions. They alter the immediate world to the benefit of the species: the constructions improve the animals' or their off-springs' chances of survival and reproduction. Many of the structural and functional achievements of animal construction are examples of astonishing perfection. Through millions of years of evolutionary development and adaptation, animal constructions have become flawless responses to their life conditions. They meet the same kind of functional needs as human architecture. Animals have developed many inventions familiar to us from our own construction: roadways (ants), covered streets (termites), deep wells (termites), heating and moisture regulation systems (termites, bees, ants and others), stairways and ramps (termites), and hinged doors (trap-door spiders) [15]. Animal constructions open up an important window on evolution, tradition and ecological adaptation.

Human behaviour and construction have become dangerously detached from their ecological context. Human architecture is always more dictated by cultural, metaphysical and aesthetic goals than by pure functionality and reason; it is also a defence against the terror of time. But, paradoxically, the human race is endangering its earthly survival by generating an uncontrolled ecological footprint.

In contrast, animal buildings fulfil strict criteria for economy and efficiency through minimizing the use of material and labour. Certain animals, such as spiders and some wasp species, eat their structures in order to reuse their building material. The capture net that certain spiders eat bypasses their digestive system and re-enters directly the silk glands and spinnerets; this short-circuit prevents the unnecessary breaking down of proteins.
Although eating our own constructions might be somewhat extreme, animal architecture does show us that a proper way towards an ecologically sound human architecture, which is urgently needed today, is not through regressing back to primitive forms of construction and materials, but through extreme technological sophistication driven by innovation. But this refinement needs to be ecologically grounded! Evolution works towards ever subtler refinement, not backwards. More importantly, however, the unsurpassable marvels of animal construction should teach all of us a welcome sense of humility [15].

Nature uses very few materials in itself. Ekmekçi, mentioned in the paper by Yeler and Yeler [16] indicates that there exist only four polymer fibres, including silk in spiders' web, chitin in insects and crustacean, collagen in animals and cellulose in herbs. The materials of the natural world show peerless features such as self-generation, hierarchical structuring, multi-functional behaviour, adaptation of structure and form to the function, adaptation to changing environmental conditions, self-repairing, self-replicating, re-adjustment, establishing of chemical equilibrium, non-linearity, compositeness, lightness, durability and biodegradation.

Also, the cyclical qualities of natural systems are brilliant. All natural ecosystems involve elements, nutrients and metabolisms in which everything is used and reused in a continuous cycle. Waste virtually does not exist in nature because each organism's processes contribute to the health of the whole ecosystem. One organism's waste is food for another, while nutrients and energy flow perpetually in closed-loop cycles of growth, decay and rebirth. Also, solar energy powers ecosystems directly or indirectly [17].

When the features of materials in nature are taken into consideration, today's construction industry must predicate nature as a model for finding a solution to its problems. The search for sustainable construction materials engineering must be made on all levels, from nanostructure up to macrostructure. The construction industry must primarily accomplish the "zero waste management system" of nature.

Current waste management activities in construction mostly focus on decreasing waste, as shown in Fig. 1.

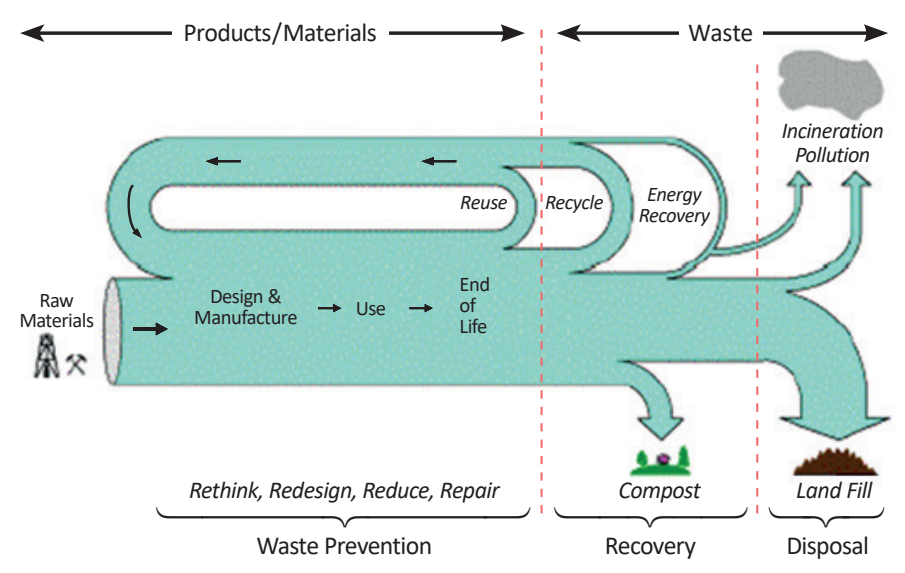

Fig. 1. Material flows in today's construction industry [16] 
However, waste must be prevented rather than limited and or even recycled, in order for construction to produce positive inputs, the goal being a "zero waste" system, as in Fig. 2.

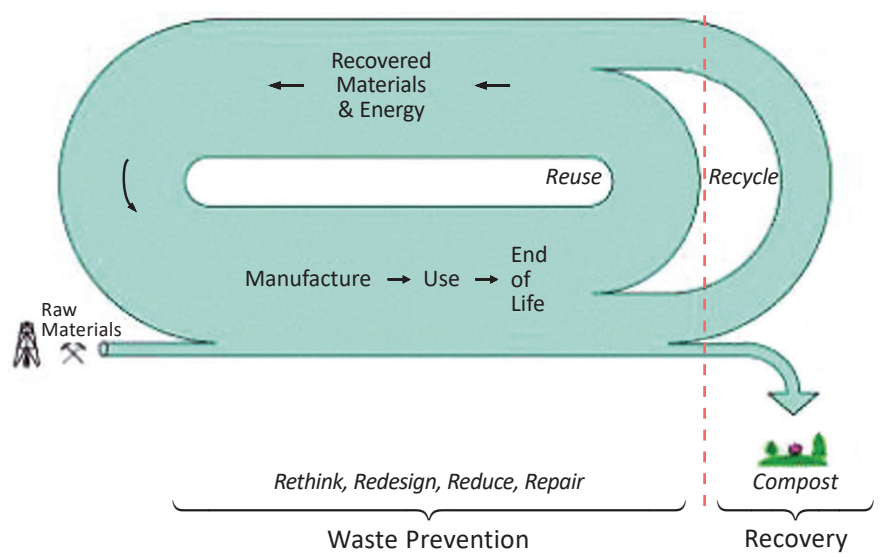

Fig. 2, Ideal, improved material flows [16]

The zero waste approach aims to provide zero waste in product life cycle, zero waste in production and management activities, zero emission, zero harmful waste and zero solid waste combined with $100 \%$ effective use of energy, raw materials and human resources. As in the natural cycle, waste of a production activity must be a source of another production activity: it's a waste to waste your waste! (Fig. 3).

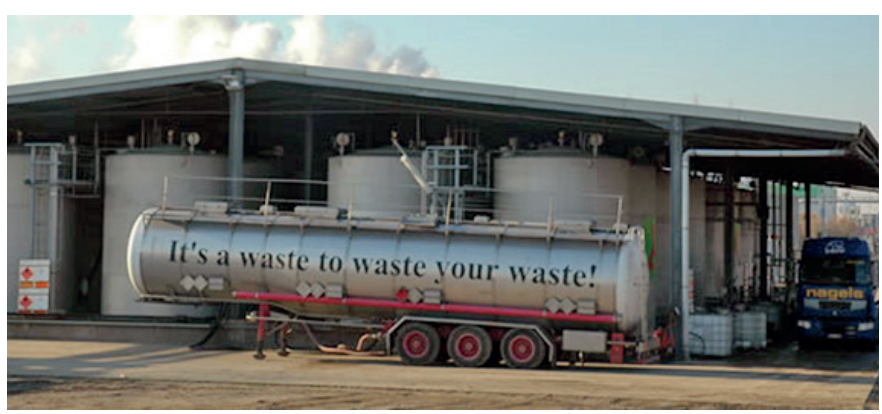

Fig. 3. Courtesy of De Neef Chemical Processing, Belgium

A zero-waste, ideal material flow would create a fully sustainable construction industry but the world community is far away from that goal! However, we have to realize that nature had the advantage of about 4 billion years to develop and adapt, that animal life started about 450 million years ago, and that the human race only started some 6 million years ago. We might think that we still have millions of years to go to reach the same sustainability level as animal life. But this is based on the assumption that humans will be able to adapt to environmental conditions, which change much faster than before. And the problem is that humans themselves are the cause of the changes which their own evolution cannot follow. Awareness of the problem is not reflected in the results of all the climate conferences up to now (Conference of Parties - CPO 23 - in Bonn in 2017 [18]). The next chapter highlights some areas of construction materials engineering where innovations contribute to sustainable development.

\section{Lesson from the past - building technology evolution}

The New Stone Age (roughly from 9000 BC to 5000 BC) was the last period of the age before wood working began. The nomadic hunter-gatherers built simple shelters and tents, using locally available materials and traditional designs and methods, known as vernacular architecture. Building tools were made of natural materials like bone, stone or wood. Human shelters were at first very simple and perhaps lasted only a few days or months. Over time, however, even temporary structures evolved into such highly refined forms as the igloo [19].

The Copper Age is the early part of the Bronze Age. Copper came into use around $5000 \mathrm{BC}$, and bronze around $3100 \mathrm{BC}$. Bronze (copper-tin alloy) was cast into desired shapes, and could be recast when damaged. The saw was invented, and bronze was used to harden the cutting edge of tools. Also the wheel was invented, and slowly replaced sledges and rollers for moving heavy loads. Gradually, more durable structures began to appear, particularly after the advent of agriculture, when people began to stay in one place for longer periods. The first shelters were dwellings, but later other functions, such as food storage and ceremony, were housed in separate buildings. Some structures began to have symbolic as well as functional value, marking the beginning of the distinction between architecture and building. The corbelled arch came into use, and the Egyptians began building stone temples with the post and lintel construction method. The Greeks and Romans followed this style.

The Iron Age is the period from roughly $1200 \mathrm{BC}$ to $50 \mathrm{BC}$. Iron is not much harder than bronze but, by adding some carbon, hard and durable steel could be produced after about $300 \mathrm{BC}$.

The history of building is marked by a number of trends. One trend is the increasing durability of the materials used. Early building materials were perishable and included leaves, branches and animal hides. Later, more durable natural materials such as clay, stone, and timber and, finally, synthetic materials such as brick, concrete, metals and plastics were used. Another is a quest for buildings of ever greater height and span; this was made possible by the development of stronger materials and by knowledge of how materials behave and how to exploit them to greater advantage. A third major trend involves the degree of control exercised over the interior environment of buildings: increasingly precise regulation of air temperature, light and sound levels, humidity, odours, air speed, and other factors that affect human comfort have all became possible. Yet another trend is the change in energy available to the construction process, starting with human muscle power and developing toward the powerful machinery used today. Even more important is today's virtually unlimited potential of IT tools: BIM (Building Information Modelling + Building Information 
Management ) acts as an integrator of technical knowledge, project management and multi-dimensional digital modelling of the design and construction process. Implementing the requirements of sustainable development should become superior to any other requirements.

\section{Innovation by itself: discovery of study results}

In the cognitive sense, the question arises of whether innovation is a discovery or a result of a task oriented study. Just discovering stands for "do something" while inventing means "let it happen". If we use the first concept, one can expect that regardless of currently implemented innovations, there is still an undiscovered collection of Innovations (with a capital "I") that we are not aware of. Gradual discovery of the I-matrix is possible owing to the improvement of our cognitive apparatus (compare the maps of innovation capability in the next chapter). However, in such case innovations would not be preordered or learned. But they could still be expected, stimulated and rewarded.

Until now, innovation never occurred in a regular way. Yet recently the innovation expectation is so great that it almost credits causative force. LAB-FAB-APP - the three abbreviations will describe the European future that we want. They stand for: Labs - research, Fabs - innovation competitive fabrication and Apps - applications for the benefit of all [20]. Symptomatic is the transition from traditional Research \& Development (R\&D) to Research \& Innovation (R\&I) [21]. If real innovation in engineering would be treated as such implemented in practice, then R\&I sounds like taking a shortcut. Beyond some spectacular brainwave like "Archimedes in a bathtub" or "an apple on Newton's head", the chain of values seems to be longer: ideas - research - discovery/innovation - validation/verification - implementation - benefit.

The idea comes first [5], then discovery is only a forerunner of innovation. As the Viking said to Columbus: America can only be discovered once. In building activity innovation means implementation: it does not mean invention only, but it refers to application in practice. The building innovation could not only be a new product but also a new way of construction erection.

Innovation is closely related to development in Schumpeter's theory of economic development: economic development is driven by the discontinuous emergence of new combinations (innovations) that are economically more viable than the old way of doing things (Schumpeter, 1934). Schumpeter's innovation concept covers five areas:

1. The introduction of a new good or a new quality of a good (product innovation);

2. The introduction of a new method of production, including a new way of handling a commodity commercially (process innovation);

3. The opening of a new market (market innovation);

4. The conquest of a new source of supply of raw material or intermediate input (input innovation);

5. The carrying out of a new organization of industry (organizational innovation).
It is an essential feature of innovation that it is something that is carried into practice, and further that the entrepreneur leads others in the same branch to follow, i.e. the innovation gets diffused through imitation [22, 23].

It means that technological innovations are only one of fundamental requirements of development. The innovation, however, builds up economic position and assures competitive dominance.

\section{Construction innovation capability}

It is not possible to discover the I-matrix all at once. However, there is necessity to make systematic efforts to do that. Some trials have already been done [3]. Main keywords relevant to innovative construction challenges have been gathered (Fig. 4). It should be emphasized that this matrix has no direct connection with innovation, but is a step ahead of the very innovative challenges.

Innovative challenges of construction technology

\begin{tabular}{|c|c|c|c|c|c|}
\hline \multicolumn{2}{|c|}{ Challenges } & Tasks & \multicolumn{2}{|c|}{ Sources } & nditionings \\
\hline$\nabla$ & $\nabla$ & $\nabla$ & $\downarrow$ & $\nabla$ & $\nabla$ \\
\hline $\begin{array}{c}\text { Facility vs } \\
\text { environment }\end{array}$ & $\begin{array}{l}\text { Buildings } \\
\text { and energy }\end{array}$ & $\begin{array}{l}\text { Building } \\
\text { structures }\end{array}$ & $\begin{array}{l}\text { Building } \\
\text { curtains } \\
\text { / partition } \\
\text { walls }\end{array}$ & $\begin{array}{c}\text { Building } \\
\text { Materials } \\
\text { Engineering }\end{array}$ & $\begin{array}{l}\text { Construction } \\
\text { Industry } \\
\text { Projects } \\
\text { Engineering }\end{array}$ \\
\hline $\begin{array}{l}\text { cities of the } \\
\text { future }\end{array}$ & $\begin{array}{l}\text { energy } \\
\text { efficiency }\end{array}$ & $\begin{array}{l}\text { durability and } \\
\text { reliability }\end{array}$ & $\begin{array}{c}\text { metal-glass } \\
\text { walls }\end{array}$ & $\begin{array}{c}\text { sustainable } \\
\text { building } \\
\text { materials }\end{array}$ & $\begin{array}{c}\text { multi- } \\
\text { dimensional }\end{array}$ \\
\hline $\begin{array}{l}\text { building- } \\
\text { environment }\end{array}$ & $\begin{array}{l}\text { air comfort } \\
\text { and quality }\end{array}$ & $\begin{array}{c}\text { "going } \\
\text { underground" }\end{array}$ & $\begin{array}{l}\text { elements from } \\
\text { building glass }\end{array}$ & $\begin{array}{l}\text { cements and } \\
\text { concretes }\end{array}$ & mechanisation \\
\hline $\begin{array}{l}\text { the } \\
\text { preferences } \\
\text { of the } \\
\text { residents }\end{array}$ & water supply & $\begin{array}{l}\text { pre-stressed } \\
\text { structures: } \\
\text { large spans, } \\
\text { heavy loads }\end{array}$ & $\begin{array}{l}\text { metal-glass } \\
\text { roofs }\end{array}$ & $\begin{array}{l}\text { insulation } \\
\text { products }\end{array}$ & $\begin{array}{l}\text { innovation and } \\
\text { competitiveness }\end{array}$ \\
\hline $\begin{array}{c}\text { transport } \\
\text { infrastructure }\end{array}$ & $\begin{array}{l}\text { automation } \\
\text { and } \\
\text { managment } \\
\text { systems }\end{array}$ & $\begin{array}{l}\text { monitoring } \\
\text { and } \\
\text { diagnostics }\end{array}$ & $\begin{array}{c}\text { thermic } \\
\text { compartments } \\
\text { compartments } \\
\text { and joints }\end{array}$ & smart materials & $\begin{array}{c}\text { digital } \\
\text { construction } \\
\text { and BIM }\end{array}$ \\
\hline & & & solar energy & $\begin{array}{c}\text { paper as } \\
\text { a building } \\
\text { materials }\end{array}$ & \\
\hline
\end{tabular}

Fig. 4 Main keywords relevant to innovative challenges in construction [5]

The contour map of construction innovation capability (Fig. 5) covers [5]:

- conditioning: social, ecological and energy related;

- basic innovation sources: building materials engineering and construction industry project engineering; 


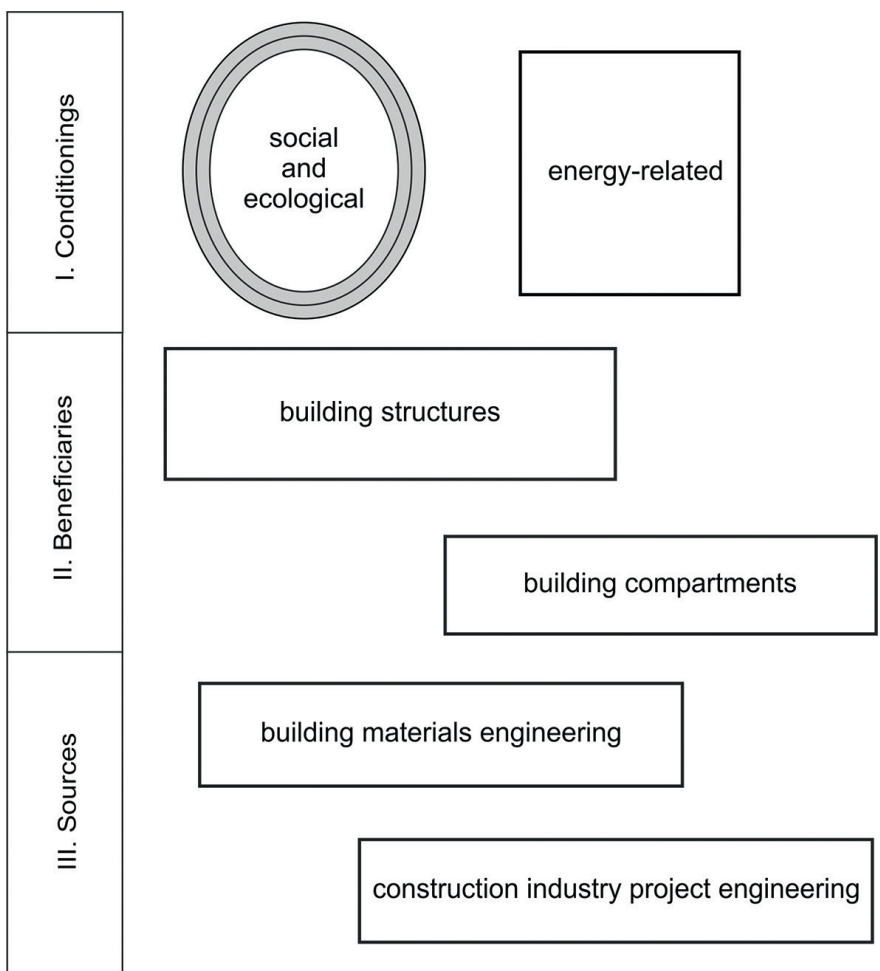

Fig. 5. Contour map of construction innovation capability [5] and additionally:

- main potential beneficiaries emerge: building structures and building curtain/partition walls.

As the contour map suggests, the selected thematic areas identify conditions for innovation (user, environment, energy efficiency), indicate the main addressee of the activities (building structures and partitions as a special building element) and point the areas of civil engineering as a scientific discipline where one can now observe the greatest innovation potential, i.e. building materials engineering and building projects engineering. Clear highlighting of building partition was determined by the fact that contemporary partition walls are not only elements which separate the building interior from the external environment but they actively affect the energy balance of a building. Examples of innovation can be found in this area in particular.

\section{Construction innovation in the holistic approach}

The big idea that innovation in construction can combine seemingly separate concepts and explain hidden added values in a simple way is shown schematically in Fig. 6. The specificity of construction innovation is determined by the demographic focus and collateral social needs which could be described as

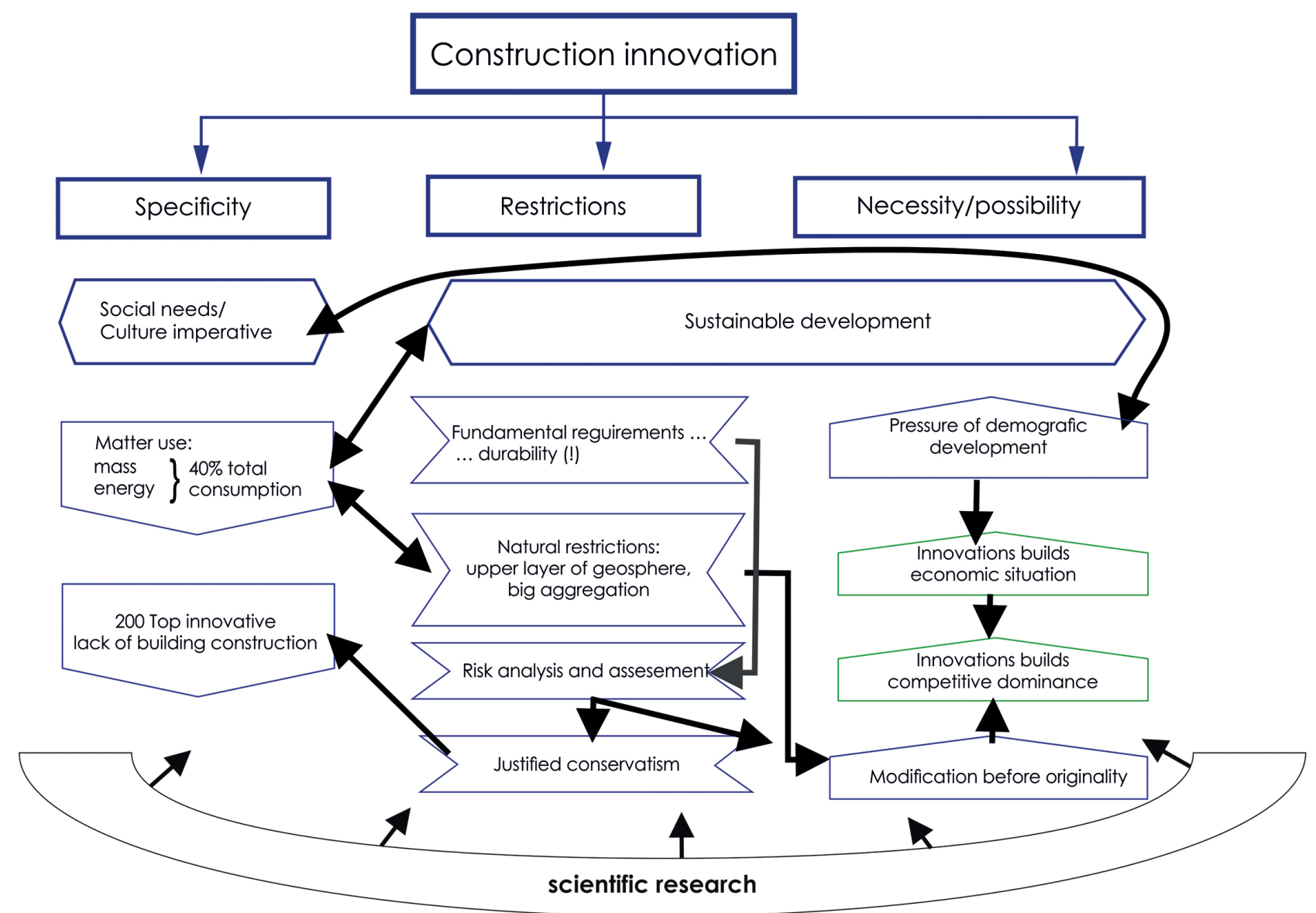

Fig. 6. Schematic presentation of construction innovation in the holistic approach 
culture imperative. The great material mass and energy consumption make the requirement of sustainable development a civilizational necessity.

As a consequence, material solutions in the building industry are restricted to the raw materials existing in the upper layer of the geosphere and in high concentration deposits. This means "modified concrete" rather than "new concrete". Paradoxically, modified concrete, although basically with the same components, can demonstrate quite new performance.

Due to their social functions and housing expectations - particularly safety (and related responsibility), building structures should fulfil the basic requirement (CPR-EU 305/2011) and assure durability - of more than fifty years.

Public trust is crucial in matters related to building. Prior to their implementation, independent sources of building innovation should be analysed and assessed on a scientific basis.

Competitive development impels innovation to build prosperity and dominance. However, reasonable conservatism in civil engineering is quite natural and fully justified. Researchers have applied a new idea, building the balance of "innovation hunger - reasonable conservatism" and this creates a filter for rational progress.

\section{Conclusions}

Innovation in construction - ideas are the currency of the future. Some are convinced that, besides the currently implemented innovations, there is a large collection of Innovations (with a capital "I") that we are not yet aware of. Gradual discovery of the I-matrix is possible owing to improved cognitive apparatus. Innovation will take place if those Innovations can provide entirely new ways to solve old problems in engineering practice.

Acknowledgements. Some issues of this paper were discussed during the $63^{\text {rd }}$ Scientific Conference of Civil Engineering of the Polish Academy of Sciences and the Science Committee of the Polish Association of Construction Engineers and Technicians in 2017, and also presented in the monograph titled "Innovative challenges of building technology" (in Polish). Edited by L. Czarnecki, ITB, Warsaw 2017.

\section{REFERENCES}

[1] http://innovationaward.cic.hk/en/about (Access online: 31.07.2017)

[2] Chartered Institute of Building, CIOB www.ciob.org/about (Access online: 31.07.2017).

[3] L. Czarnecki (ed.), Innovative Challenges of Building Technologies, ITB, Warszawa 2017 [in Polish].
[4] C. King, Research Front Maps, Thomson Reuters. http://archive. sciencewatch.com/dr/rfm (Access online: 31.07.2017).

[5] L. Czarnecki, J. Deja, K. Furtak, A. Halicka, O. Kapliński, M. Kaszyńska, M. Kruk, K. Kuczyński, E. Szczechowiak, and J. Śliwiński, "Ideas shaping innovation challenges of construction technology", Materiaty Budowlane 7/2017, s. 28-39 [in Polish].

[6] M. Kaszyńska and S. Skibicki, "Structural failures and disasters as the source of innovative solutions in construction", in Innovative Challenges of Building Technologies (ed. L. Czarnecki). ITB, Warszawa 2017 [in Polish].

[7] L. Czarnecki and H Justnes, "Sustainable \& durable concrete". Cement Lime Concrete 6/2012, s. 341-362.

[8] L. Czarnecki, "Sustainable concrete; is nanotechnology the future of concrete polymer composites?", Advanced Materials Research 687/2013, p. 3-11.

[9] H. Daly, Beyond Growth: The Economics of Sustainable Development, Boston, Beacon Press, 1996.

[10] L. Czarnecki and D. Van Gemert, "Scientific basis and rules of thumb in civil engineering: conflict or harmony?", Bull. Pol. Ac.: Tech. 64 (4), 665-673 (2016).

[11] L. Czarnecki and J.J. Sokołowska, "Material model and revealing the truth", Bull. Pol. Ac.: Tech. 63 (1), 7-14 (2015).

[12] https://www.timeshighereducation.com/news/worlds-best-institutions-influencing-inventions-revealed (Access online: 21.11.2017).

[13] https://www.lens.org/lens/in4m\#/rankings/global/locations (Access online: 21.11.2017).

[14] Chandra S., History of Architecture and Ancient Building Materials in India, Tech Books International, New Delhi 110 019, India, 2003.

[15] Pallasmaa J., Architecture of the Essential: Ecological Functionalism of Animal Constructions, http://www.solaripedia.com/ files/1062.pdf, (Access online 20.11.2017).

[16] Yeler G. and Yeler S., No Waste in Nature: Using Nature as a Model for Construction Industry, ICOEST, Cappadocia, Turkey, 2013.

[17] D. Eisenberg and W. Reed, "Regenerative design: Toward the re-integration of human systems with nature", 2003.

https://www.usgbc.org/Docs/Archive/MediaArchive/308_Reed PA333.pdf (Access online 20.11.2017).

[18] https://cop23.unfccc.int/ (Access online 20.11.2017).

[19] https://www.britannica.com/technology/building-construction, (Access online 20.11.2017).

[20] P. Lamy, "LAB-FAB-APP. Investing in the European future we want", European Commission, Luxemburg 2017.

[21] C. Moedas, Research and Innovation - Shaping Our Future, http://europa.eu/rapid/press-release_SPEECH-17-1881_en.htm (Access online 20.11.2017).

[22] I. Drejer, "Identifying innovation in surveys of services: a Schumpeterian perspective", Research Policy 33 (3), 551-562 (2004).

[23] J.A. Schumpeter, The Theory of Economic Development: An Inquiry into Profits, Capital, Credit, Interest and the Business Cycle, Harvard University Press, Cambridge, 1934. 